\title{
Article
}

\section{Hamid Taieb}

\section{Acts of the State and Representation in Edith Stein}

https://doi.org/10.1515/jso-2019-0017

\begin{abstract}
This paper discusses the thesis defended by Edith Stein that certain acts can be attributed to the State. According to Stein, the State is a social structure characterized by sovereignty. As such, it is responsible for the production, interpretation, and application of law. These tasks require the performance of acts, most of which are what Stein calls "social acts" like enactments and orders. For Stein, the acts in question are made by the organs of the State, but in the name of the State, and are thus attributed to the State via a relation of representation. In the first section, the paper presents Stein's thesis that the sovereignty of the State entails a series of legal prerogatives, which in turn result in various social acts being ascribed to the State through its representatives. In the second section, the paper critically discusses Stein's views, notably her theory of representation, and her account of the nature of the State, while emphasizing its most interesting aspects, namely, its fine-grained analyses of the various acts that are attributed to the State.
\end{abstract}

Keywords: Edith Stein; Theory of the state; Social acts; Representation; Phenomenology of law.

\section{Introduction}

Political activists are victims of the State's repression, while well-off citizens benefit from its protection. The State takes care of public spaces. It levies taxes in order to finance its actions. To meet its own operational needs, the State also enters employment contracts and commercial agreements as a party. When the State does not restrict itself to the defence of public order, it performs a great

\footnotetext{
Hamid Taieb, Department of Philosophy, University of Hamburg, Überseering 35, Postfach 4, 22297 Hamburg, Germany, Phone: +49.40 .42838 .4714 , e-mail: hamid.taieb@uni-hamburg.de
} 
number of other acts: establishing schools, building hospitals, organizing cultural events, launching awareness campaigns on health, etc. The State thus seems able to perform a wide range of acts. However, one may also object that none of these is ultimately to be attributed to the State itself: after all, political activists are victims of police officers, public spaces are taken care of by builders, schools are established by mayors, and so on. Why would one need to ascribe such acts to the State itself? Indeed, how could the State have acts attributed to it at all if it is not a person? Perhaps the State can have acts ascribed to it via its organs, who are indeed persons (whether individuals or collectives); one would then have to say that police officers, mayors, etc., are organs of the executive power of the State and act in its name, and so their acts are ultimately ascribed to it. But if this is accepted, is there a limitation of the kinds of act that one could ascribe to the State? For example, besides the conclusion of a contract in which the State is a party, are the thoughts of the civil servant during negotiations, her enthusiasm, hesitation, and fear, or the movement of her hand as she signs the document all acts of the State?

These questions, which are at the intersection of social ontology and philosophy of action, are answered in detail in the work of Edith Stein. ${ }^{1}$ Stein offers an explanation of why and how some acts must be attributed to the State. Her main thesis is that acts can be attributed to the State via a specific relation, that of representation. This relation holds between the State and its representatives: the latter act in the name of the State, which thus becomes the subject of these acts. However, the relation of representation does not allow for the ascription to the State of acts of all kinds. The State is defined by its sovereignty, which implies that it is the "source of its law". Now, being such a source requires an ability to act - namely, the ability to produce laws. Yet the State not only must produce laws, but must also interpret them and apply them; these are further acts that must be attributed to the State. Interestingly, Stein provides a detailed taxonomy of the acts that are ascribed to the State, which include all and only those acts which constitute the exercise of its legal prerogatives; the relation of representation thus concerns only those acts. The acts in question are mostly what Stein, following Reinach (1913a), calls "social acts". By means of social acts, the State is able to produce, interpret, and apply laws. The acts which serve as the foundations of these social acts - i.e. cognitions and volitions - or which are conditions of these acts - e.g. bodily movements - are not ascribed to the State itself, but to its representatives.

1 On Stein's works in general, see the papers gathered in Magrì and Moran 2017, as well as the introduction of the editors. On her social and political philosophy and phenomenology more specifically, see Calcagno 2014, as well as De Vecchi 2015, 2017. 
This paper presents and evaluates Stein's views on the attribution of acts to the State. The first section presents Stein's thesis that the State's sovereignty and the legal prerogatives that it implies, lead to the ascription to the State of social acts via a relation of representation. The second section evaluates Stein's views; it criticizes her theory of representation and her account of the nature of the State while acknowledging the value of her fine-grained analyses of the various acts to be attributed to the State.

\section{Stein's Account}

Is there any reason to attribute acts to the State? Can a social structure such as a State act at all? Does it act through its organs? If this is conceded, what is the criterion for determining which acts of the organs are to be attributed to the State and which ones are not to be attributed to it (e.g. the organ's reflections, emotions or bodily movements)? As indicated in the introduction, Stein provides answers to these questions; but in order to understand her answers, a presentation of her general account of the State is needed. For Stein, the State is a social structure characterized by its sovereignty. Sovereignty, in turn, entails the ability to produce laws, as well as to interpret and apply them, and this requires that certain acts be attributed to the State. In other words, the legal prerogatives of the State provide a criterion as to what kinds of acts are to be attributed to it. Thus, before entering into a detailed discussion of the attribution of the acts to the State, some preliminary remarks on the nature of the State are required.

\subsection{Preliminary Remarks: The State as a Social Structure Characterized by Sovereignty}

For Stein, the State counts as a "social structure" (soziales Gebilde); Stein asks whether this social structure can be brought back to already known "social types" (soziale Typen) or "living together of subjects" (Zusammenleben von Subjekten) (2006, p. 5, Sawicki, p. 2). ${ }^{2}$ The types accepted by Stein are mass, community, and society. Masses are pluralities of individuals who exert an influence on one another, but without knowing it. In a community, by contrast, the members not only mutually motivate one another and have shared states of mind, such as beliefs and emotions, but also are conscious of sharing them. In societies too, this conscious-

2 In addition to the references of the Gesamtausgabe edition of Stein's text on the State, I give the pages of the translation by Sawicki. All translations in the body of the text are mine; all translations in block quotations are by Sawicki, with some modifications by me. 
ness is given, but with the difference that the society has been built in order to reach a specific goal, whereas the life of the community is not similarly determined by a goal. ${ }^{3}$ It might seem that Stein treats the State as a specific kind of community, since she talks of it in terms of a "community structure" (Gemeinschaftsgebilde) (2006, p. 9-17, Sawicki, p. 7-16). However, when she enters into the details of the relation of the State to communities, she seems to defend a rather different view. For Stein, although the State resembles communities, it is apparently not in itself a community, as affirmed in the following text (2006, p. 38, Sawicki, p. 48):

The community of individuals living in a State is still not a State. The fact that its citizens form a community may be the basis for the State's existence or may be a consequence of living under its law, and the community then belongs to the substance (Bestand) of the State - but the State itself is not the community.

What Stein seems to be saying is that a State is always based on a community; this community can, but does not necessarily need to be, a "people" (Volk), that is, a series of individual persons sharing a common culture, be it scientific and artistic, or simply a "stylised form of life" (2006, p. 17-18 and 20, Sawicki, p. 16-21 and 23). The community in question does not even need to be already given: by its very existence, the State builds a community, namely, the community of the persons submitted to it (2006, p. 18 and 38, Sawicki, p. 20 and 48; and the explanation by Riedel-Spangenberger, in Stein 2006, p. 18 n. 46). It seems that for Stein, the State has its "proper form of existence", which is distinct from that of the persons that are within its sphere of power (Loidolt 2010, p. 115-116). ${ }^{4}$

What is the mark of the State? According to Stein, the State's characteristic property is its sovereignty (2006, p. 11, Sawicki, p. 9):

The State has got to be its own master. The modalities of the life of the State may not be prescribed for it through any power standing outside of that State - be it a private person or be it a community superior, collateral, or subordinate to that State.

3 Given the long description provided in Stein 2010 (p. 110-262), the distinction between mass, community, and society is only briefly mentioned in Stein's text on the State (see 2006, p. 5-9, Sawicki, p. 2-6). On these categories, see Riedel-Spangenberger in Stein 2006, p. 7 n. 14, Salice 2015, as well as Szanto and Moran 2015; the opposition between community and society famously comes from Tönnies 2016.

4 On the fact that the State is not a community, in addition to Loidolt 2010, see RiedelSpangenberger, in Stein 2006, p. 8 n. 15: "For Edith Stein none of the three types of sociality mentioned is enough alone to characterize the structure of the State. Stein, however, pursues only the possibility that States build themselves on the basis of the life of a community." For a different reading, according to which the State is identical to a community, see De Vecchi 2015, p. 306. 
In other words, the essence of the State is to be a sovereign social structure. This has nothing to do with empirical considerations about the form of the various States in the history of humanity. As an early student of Husserl, and thus a member of the Munich-Göttingen phenomenological tradition, Stein insists on the importance of essential analysis in philosophy. The task of philosophy is to grasp atemporal essences, which are ideal Platonic objects with a specific mode of being. ${ }^{5}$ This programme also applies to Stein's inquiries on the State. As she insists, it is not necessary that a State gather together human beings, nor that it exists on Earth; there could be a State which contains merely "spiritual” (geistig) beings and exists without any territory (2006, p. 79-80 and 92, Sawicki, p. 106 and 126):

The State encompasses a range of persons (who need not necessarily be human beings) [...] note that you can not dismiss the possibility of a State whose foundation would be purely spiritual persons.

Sovereignty is explained in juridical terms: it means, for an entity, that "all the positive law in its domain can be traced back to itself", or more simply that it is "the source of its law" (2006, p. 12 and 37, Sawicki, p. 10 and 46). For Stein, this very general account of the essence of the State allows for many organizational specifications: there can be a single person in charge of the legal decisions, or a few people, or the decisions can belong to all the citizens. In other words, the State can take various forms: it can be a monarchy, an aristocracy, or a democracy (2006, p. 28-29, Sawicki, p. 33-34). As long as there is a social structure which is sovereign, there is a State, no matter what specific form it takes.

\subsection{Acts Required by the State's Establishment of Laws}

As indicated above, the question of why acts are to be attributed to the State, and what acts they are, is given a detailed answer by Stein. According to her, the attribution of acts to this social structure is required by its being sovereign, that is, its being "the source of its law", which entails the "establishment of laws". This legal prerogative, if it is to be achieved and applied, in turn entails the attribution to the State of two other kinds of acts - namely, the "pronouncement" and

5 On Stein's conception of philosophy, see 2008. For a presentation of Stein's main ontological assumptions (made, incidentally, in the context of a discussion of her theory of the State), see Gombócz and Salice 2006. For philosophy as Wesensschau, see also Reinach 1913b and 1914, and the origins of this in Husserl 1984. For more on the Munich-Göttingen tradition, see Salice 2015. For an analysis of the eidetic nature of Stein's inquiries on the State, see De Vecchi 2015. 
"execution" of laws. In sum, the criterion for the attribution of acts to the State is whether these acts are required by the exercise of the legal prerogative of the State. As will be shown, the acts that can be attributed to the State are mostly "social acts", which the State can perform thanks to the action of "organs" which act as "representatives"; while the State itself is not a person, these organs are either individual or collective persons. The present (rather long) subsection is devoted to the discussion of the "establishment of laws", in the course of which I will present the crucial notions of social act and representation; the next, shorter, subsection will discuss the pronouncement and execution of laws. This will make it possible to clarify the exact taxonomy of acts that Stein attributes to the State, given its various legal prerogatives.

The State, for Stein, is the "source of its law". The word "source" (Quelle) implies some sort of genetic relation: the State seems to be a producer of law. But the question then arises as to what exactly the nature of this production is. Stein has a precise answer: she speaks of the production in question as an "establishment of laws” (Rechtssetzung) (2006, p. 34 and 41, Sawicki, p. 40 and 52). This establishment is understood as a specific type of act; more precisely, following Reinach (1913a, p. 158-169), Stein understands the "establishment of laws" in terms of "enactments" (Bestimmungen). Enactments, in Reinach (1913a, p. 238-251), are a species of social act. ${ }^{6}$ A social act is a spontaneous intentional mental act which not only "relates itself to someone else", as e.g. forgiveness does, but must also be "received" (vernommen) by someone else in order to be accomplished, as orders, e.g. do (1913a, p. 158-159). Note that the word "intentional" here does not refer to volition, but to intentionality, that is, the mind's "aboutness", or directedness towards an object, broadly understood; 7 this means that social acts are about something, for example, a state of affairs. An enactment is a social act which posits that some state of affairs or some behaviour ought to be (1913a, p. 243-244). In contrast to an order, however, an enactment never prescribes something to someone in particular, though it does require that someone receives it (1913a, p. 242; for Reinach's account of enactment, I follow Schuhmann 2004, p. 178-180).

Stein borrows from Reinach the notions of social act and of enactment, including the thesis that enactments are spontaneous, that is, that they are "free" or "voluntary" acts (freie, willentliche Akte) (2006, p. 35 and 37, Sawicki,

\footnotetext{
6 Reinach's notion of social act anticipates the more recent theory of speech acts (Mulligan 1987), that is, "those acts that can (though need not) be performed by saying that one is doing so" (Green 2014).

7 Reinach literally speaks of an "objectuality” (Gegenständlichkeit), which seems to refer to Husserl (1984, p. 45), who says that he uses this term broadly to refer not only to "objects" (Gegenstände), but also to states of affairs, properties, etc.
} 
p. 42 and 46). ${ }^{8}$ Thus, for Stein, the State's sovereignty entails that it performs a specific kind of free act, namely, the "establishment of laws" (Rechtssetzung), understood as a series of "enactments" (Bestimmungen) (2006, p. 34 and 41, Sawicki, p. 40 and 52). ${ }^{9}$ But Stein also adds an important qualification: the previous considerations attribute to the State a "free spiritual activity" (freies geistiges Tun), whereas it is normally only persons that are the subjects of free acts (2006, p. 34, Sawicki, p. 46):

Spontaneous acts are free spiritual activities, and we call the subject of such activities a person.

What Stein means by "person" is a free spiritual being with value sensitivity, submitted to laws of rationality and which constructs itself into a "meaningful unity" (Sinneinheit) (see e.g. 2008, p. 116-126 and 2010, p. 159-163)..$^{10}$ Persons are either individual or collective. Stein does not provide much detail about her notion of collective person; the example she mentions is an "association" (Bund), which "decides to the extent that its members decide together, and for it and each of them gives its approbation from itself” (2006, p. 37, Sawicki, p. 47). She seems to understand collective persons as entities able to make decisions on their own, on the basis of the decisions of the individual persons that constitute them, but does not equate the two levels of decision. Furthermore, the example seems to imply that societies can be collective persons, but it is neither clear whether all societies are collective persons, nor whether communities can be collective persons (although it is likely that they are, provided they can make collective decisions). ${ }^{11}$ In any case, for Stein, the State itself is neither an individual person nor a collective person. Moreover, as already indicated above, the State is to be conflated neither with the

8 For more on free acts in Stein, see 2010, p. 45-53. Note that "acts" (Akte) in Stein can be either passive or active, and active ones are to be divided into "activity" (Tun) and "action" (Handlung). I come back to this below.

9 For a careful analysis of the conditions to be fulfilled for an enactment to be efficacious, and for Stein's originality on this question relatively to Reinach, see De Vecchi 2017.

10 Note that Stein distinguishes between, on the one hand, beings which have experiences and self-awareness, which I will call "mental" beings, and on the other hand, "spiritual" (geistig) beings, which are mental beings subject to motivation. Spiritual beings are not just submitted to instinctive "stimulation" (Reiz) and "reactions", but are also sensitive to values, including ethical and aesthetic ones, and thus act on the basis of reasons. Stein does not deny that some animals might be counted as spiritual beings, but only persons have free spiritual activity (see 2010, esp. p. 21-24, 35-53, and 148-152).

11 Stein's notion of collective person is probably borrowed from Scheler 1980. On Scheler's theory of collective persons, see Salice 2016. On Stein's account of mass, community, and society, see again 2010, p. 110-262. 
"people" (Volk) which is in its own sphere of power, nor with the possible community that is created due to its being submitted to the State (2006, p. 38, Sawicki, p. 48). However, despite not being a person, the State can have free spiritual acts attributed to it. For Stein, this is to be explained through the notion of "representation”, which, as indicated above, is a key notion of her account.

Representation is a notion which Stein also borrows from Reinach (1913a, p. 225-227). It is the power given to a person to perform social acts "in the name of" someone else, so that the rights and obligations which are produced by a social act are ascribed not to the representative, but to the person represented. The relation of representation is thus a triadic relation among two persons and a social act. It is in the nature of representation to produce rights and obligations for someone else, and producing rights and obligations is a property of social acts. Reinach speaks of this relation in terms of a "modification" of social acts; for when they are performed in the context of representation, they have the peculiar feature of being ascribed to someone other than the person who is performing them (1913a, p. 165 and 223). ${ }^{12}$ For Stein, the State can be represented by persons, who thus perform enactments "in the name of" the State. By the relation of representation, the State becomes the "subject" (Subjekt) of the acts made in its name, even though it is not a person; thus, the State's ontological status seems ultimately to be that of a sui generis subject of free spiritual acts (2006, p. 37-38, Sawicki, p. 46-48; on representation, I rely on Schuhmann 2004, p. 177-178, and Mulligan 2015, p. 33-36).

Stein gives further clues about the nature of the State as a subject. She holds that the State is a "legal subject" (Rechtssubjekt), which means that it has "the responsibility for the effective law order”. To that extent, it must be distinguished from an "ethical subject". The State is indeed responsible for the production of positive law, but not for judging whether the laws in question are of ethical value. In order to be able to make ethical evaluations, one must have value sensitivity, that is, a specific "feeling" (Fühlen) for values, which the State entirely lacks (2006, p. 119, Sawicki, p. 172). Note that Stein distinguishes the State's status as a legal subject from its status as a "juridical person" (juristische Person), that is, a "bearer of subjective rights" (2006, p. 56, Sawicki, p. 73). She explains the notion of subjective right as follows (2006, p. 56, Sawicki, p. 74):

The meaning of subjective right can be made yet more precise in that a subject is authorized to perform certain acts through a legal relation or an enactment of law, or that a category of acts is delimited whose performance by a subject eligible for them is declared to be right.

The State is a specific kind of juridical person, in the sense that it has, first and foremost, "the (subjective) right to produce (positive) law" (2006, p. 58, Sawicki,

12 I thank an anonymous referee of this journal for this idea. 
p. 76). For Stein, the use of the notion of "personhood" in "juridical person" should not be taken in the narrow sense. She clearly distinguishes the proper personhood of individual (human) persons, and non-personal social structures such as the State. However, she emphasizes that both a true person (e.g. a human being) and a non-personal social structure such as the State can be bearers of subjective rights (2006, p. 59, Sawicki, p. 77-78).

The representatives of the State are its "organs", in contrast to its "members" (Glieder), which are the persons included within the sphere of power of the State (2006, p. 38, Sawicki, p. 48). Concerning the establishment of laws, the idea is that enactments made by the organs of the State are attributed to the State. These organs vary according to the structure of the State, for example, monarchy, aristocracy, or democracy (2006, p. 75, Sawicki, p. 99). But no matter how the organs are organized, a relation of "recognition" (Anerkennung) holds between the State and its representatives, for the State must recognize the organs as its representatives and as acting in its name. This recognition can be made on a case-by-case basis, by specific approval for particular acts performed in the name of the State; or it can occur in advance, as someone can be given the power to represent the State for a specific kind of act without the need for further approval of each of the actions made by the representative. Conversely, there must be an acceptance of the power of the State by its organs. Furthermore, the members of the State have to submit themselves to it and to its legislation. Stein holds that this submission is made via a "placet" (i.e. an agreement), since the members of the State, as persons, are free. To be sure, this submission can be forced, that is, imposed upon the members of the State; interestingly, however, Stein adds that being forced still is not a matter of necessity, but of motivation, since it is meant to "convince" the people to accept the ascendancy of the State. In other words, submission to the State always derives from acceptance, even when it is given in the worst conditions, such as under threat (2006, p. 39-40, Sawicki, p. 49-52).

Stein holds that the bearer of the social acts is the State understood not as the persons who are its members, nor as any of its organs, but as a "unity" (Einheit). But what exactly is the State taken as a unity? It might seem that it is precisely the sui generis subject mentioned above, that is, a "legal subject" (Rechtssubjekt). However, Stein also says that the State is a "whole", which seems to imply some sort of multiplicity of parts (2006, p. 37, Sawicki, p. 46). One even finds her speaking as if the organs were representing not only the State, but also its members (2006, p. 39, Sawicki, p. 49):

The civil authority claims that it represents the whole State and that its law is in effect for the whole State, which means for that sector of persons who form the sphere of power of the State and who along with the State are represented by its organs. 
Does the organ thus represent the State as a subject, or its members, or perhaps two sorts of entity, namely, the State and, "along with the State”, its members? What Stein suggests simply is that the organs represent the State, not that they represent the State plus its sphere of power. So one way to interpret the passage above is that it recalls the idea that the organs, by representing the State, represent an entity which is based on an underlying community (at the very least this is the community of the persons submitted to its sovereignty). Strictly speaking, however, what the organs represent is still the State.

Stein has an interesting and detailed analysis of the exact class of acts that are ascribed to the State when it is represented by its organs. In order to understand this, one has first to see how social acts, for Stein, are related to a subject's mental life. In her psychological inquiries, as in other domains, Stein is interested in grasping the essences of experiences and their relations, in contrast to empirical psychology, which according to her does not reach beyond existing species like human beings and animals (see e.g. 2004, p. 20-22). In other words, her philosophical project understood as a general enquiry about essences (2004, p. 9) has as one of its parts what she calls a "phenomenology" of consciousness; this phenomenology is not about subjective instances of consciousness, but about its essences. This eidetic-phenomenological programme makes it possible to determine the essential relations between mental acts, including social acts and the acts on which they are based. The application of this eidetic-phenomenological approach to the State leads Stein to provide a very fine-grained account of the kinds of acts that can be attributed to the State relative to its various legal prerogatives.

As noted above, according to Stein, social acts are grounded in other mental acts, which are intentional acts, that is, directed towards an object or a state of affairs. Now, for Reinach, social acts inherit their objects from their underlying mental acts, which are of a different nature; for example, an order is based on an act of the will which has as its object that the addressee does what is demanded of him (1913a, p. 162; quoted in Schuhmann 2004, p. 180). These ideas are developed by Stein; according to her, social acts are grounded in acts of "cognizing" (Kenntnisnahme) and of "position-taking” (Stellungsnahme) (2006, p. 50, Sawicki, p. 56; transl. Loidolt 2015, p. 56). Acts of cognizing (e.g. perceptions) are "those in which some objectuality comes to be given to us". ${ }^{13}$ They are passive, in the sense that they are a kind of "reception" (Hinnehmen) (2010, p. 41-42). Acts of cognizing motivate another kind of act, that of position-taking, which, despite the name, is

13 On the notion of objectuality (Gegenständlichkeit), see the discussion above, with the reference to Husserl 1984, p. 45. 
also passive; an example is the belief in the existence of a perceived object (2010, p. 42-44). Among acts of position-taking, Stein counts acts of "volitional positiontaking" (Willensstellungsnahme), where what is willed is the bringing about of a state of affairs. Such acts are not free, that is, they are not made on the basis of free will, the idea being that one cannot spontaneously will something to be brought about (2010, p. 49-50). ${ }^{14}$ The bringing about itself is an "action" (Handlung), to be distinguished from an "activity" or "doing" (Tun), the only result of which is some behaviour of the subject. Both actions and activities are free (2010, p. 49-50). The characteristic of free acts is that they are introduced by an "impulse", a "fiat", or some sort of "push" (Ruck) (2010, p. 50). As noted above, social acts, which are also free, depend on other mental acts, as they are based on a series of underlying acts of cognizing and position-taking. For example, an order is based on a volitional position-taking with regard to a state of affairs, and this volitional positiontaking is itself based on a cognizing of the state of affairs in question (2010, p. 51-52, and 2006, p. 50, Sawicki, p. 56). ${ }^{15}$

Stein makes use of these distinctions when analyzing the acts attributed to the State. Her idea is that the relation of representation, and thus the ascription to the State of acts performed by its organs, holds only for some of these acts, not for all of them. As indicated, in order for the State to be sovereign, it must be the source of its law, which in turn implies that it also makes enactments, which are social acts. Since they are based on acts of cognizing and of position-taking, the question arises as to whether those acts are also attributed to the State. Stein's answer is no: the acts that belong to the State are those related to its being a source of law. One can say of the State that it performs enactments, but according to Stein, when we say that the State "thinks” (denkt), “reasons” (überlegt) or "experiences” (erfährt), or that it "gets angry" (grollt) or "feels sad" (trauert) (2006, p. 50, Sawicki, p. 65), this is a "mere façon de parler" - that is, we should not take such talk at face value:

[...] the State can choose, command, regulate, promise, commit itself, and so on. Can you also say, in the same way, that the State thinks or reasons, it gets angry, it feels sad, and the like? Obviously - in contrast to the cases mentioned above - it is a mere façon de parler if you use such an idiom.

The State neither cognizes nor has any feelings. Although its enactments require acts of cognizing and of position-taking as "grounds" (Grundlagen), these

14 See 2010, p. 49: "By contrast to the resolution, the volitional position-taking - as a true position-taking - is not a free act (kein freier Akt)."

15 For more on this, see 2010, 41-53, which includes references to Reinach 1911 and Hildebrand 1916. I pass over some of the acts mentioned by Stein in her general taxonomy. 
underlying acts belong to the organs of the State, and thus are not attributed to it: they are not done in its name. In other words, the relation of representation does not hold for these acts, and their subjects remain the organs themselves. A fortiori, therefore, other acts of cognizing or feelings of the organs are not ascribed to the State. Indeed, if an organ of the State makes some reasoning before proceeding to an enactment, or has some specific feeling when making an enactment, such reasonings and feelings are his own acts. In other words, the relation of representation does not hold for these acts either (see again 2006, p. 50, Sawicki, p. 65; and, on feelings, 2006, p. 119, Sawicki, p. 173). Note that since human beings are not merely mental beings, but also embodied beings, the acts of enactment by the State entail - in addition to their underlying cognizing and position-taking, and the reasoning and feeling that might accompany them - a series of concomitant bodily activities and actions, such as linguistic communication, signing, etc. However, one could certainly say that these further acts are not attributed to the State, since they are not in themselves the exercise of a legal prerogative of the State, but only conditions for their exercise. Here again, there is no relation of representation between the organs and the State, and so the State does not become the subject of these acts.

As noted above, according to Stein the State can take various forms: that is, it can be a monarchy, an aristocracy, or a democracy. These different forms of the State entail different sorts of representation. In a monarchy the King or Queen acts as a unique individual person in the name of the State, whereas in an aristocracy this is made by a small number of persons, who would probably count as a collective person for Stein, and thus as a single organ. The situation is much more complex in democracies. Are the citizens taken as a whole the organ of the State? The answer seems to depend on the form of democracy.

In a direct democracy, the citizens themselves act directly as organs or representatives of the State; they probably build a community according to Stein's criteria and thus seem to be a collective person. Note that the citizens act not in their own name, but in the name of the State. Indeed, given that for Stein the State is a sui generis entity, distinct from the underlying community on which it is based, doing something in the name of the State and doing it in the name of the citizens are not the same. The citizens act as the legislative organ of the State and thus represent this very entity; that is, they act in its name, not in the name of the underlying community. This seems to be confirmed by the following text (2006, p. 75, Sawicki, p. 99):

The State is a social structure into which free persons are inserted (eingefügt) in such a way that one or several of them (or in the limit case, all of them) govern the others in the name of the whole structure. (In that limit case, the sector of sovereignty is formed by the same persons who also exercise control, but only insofar as they do not have representative functions.) 
As the text states, even when all of the persons govern, they always do so "in the name of the whole structure" (im Namen des ganzen Gebildes), since they have a "representative function" (vertretende Funktion); they do not govern in their own name.

In a representative democracy, the situation is much more complex. How exactly does it work? Stein does not develop an account of representative democracy, but perhaps the following description might fit her overall theory. In this kind of democracy, the citizens elect individual persons, the deputies, who constitute the parliament. The parliament is most likely a society, according to Stein's typology of social structures, and thus probably a collective person. The parliament has legislative power, that is, it is in charge of the establishment of laws. Representation might work as follows: the citizens - or rather their community - have a proxy from the State to represent it by establishing laws, but they transfer this proxy to the deputies - or rather to the parliament, a collective person - so that the deputies, organized as a collective person, acquire the power to establish laws in the name of the State. In short, there is a transfer of the power to represent the State from the citizens to their deputies, or rather from the community of the citizens to the parliament, which is a society (the transfer of the power of representation, although not mentioned by Stein, is discussed in Reinach 1913a, p. 227-228; transl. Crosby, p. 87-88).

In all these cases, what is clear is that the State becomes the subject of the acts of establishing laws via a relation of representation that it enters with its organs, which are either individual persons (as in monarchies), or collective persons (as in aristocracies and democracies). In representative democracies, however, the situation is complicated, since the community of citizens, a collective person, transfers its power to represent the State to another collective person, the parliament.

\subsection{Acts Required by the Pronouncement and Execution of Laws}

The relation of representation, and thus, the attribution of acts to the State via its organs, is not restricted to the establishment of laws, but extends to two other legal prerogatives of the State, namely, the "pronouncement" and the "execution" of laws. Here again, Stein provides a detailed analysis of the acts of which the State is the subject, in contrast to those of which the organs remain the subject. A presentation of her careful description is required in order to have a complete picture of the kind of act that she attributes to the State.

The necessity of the State being able to produce laws leads Stein to attribute to it certain acts, namely, enactments. According to Stein, however, this does 
not exhaust the kinds of acts that have to be attributed to the State due to its relation to law. ${ }^{16}$ She holds that in order to be achieved, the production of law requires further acts in addition to enactments through which the law is produced. For the State is also responsible for the "pronouncement of laws" (Rechtsprechung) and performs “executive acts” (executive Akte) (2006, p. 44 and 45, Sawicki, p. 57 and 58). Stein's point seems to be that the interpretation of laws, as well as their application, must be prerogatives of the State, for otherwise its sovereignty would be incomplete, since it either would have no control over the "meaning" (Sinnesgehalt) of the laws that it produces, or it would not be able to enforce them. These three functions with respect to law is what Stein calls the "administration of law" (Rechtspflege) (2006, p. 45, Sawicki, p. 58). She further holds that in addition to these three functions, the State also acts as an "entrepreneur" (Unternehmer). This additional status is not entirely clear. The tasks that the State is supposed to fulfil as an entrepreneur are various: with respect to other states or people outside the country, Stein makes the examples of war, colonization, and business; with respect to the persons submitted to the State, Stein mentions the foundation of schools and "institutions of social care" (soziale Einrichtungen), and financial transactions (2006, p. 45, Sawicki, p. 58). The State has to act if it is to be an interpreter and executor of the laws, as well as an entrepreneur. Stein therefore gives a detailed description of the kinds of acts that must be attributed to the State via the relation of representation in order for it to fulfil each of these tasks.

The interpretation of law is an intellectual act. As seen above, Stein denies that intellectual acts are to be attributed to the State. Do the organs therefore act in their own name when interpreting the law? Will the relation of representation then be lost, and will the State consequently be deprived of the important legal prerogative of fixing the meaning of the law? In fact, Stein manages to preserve the State's control over the interpretation of law without attributing any intellectual act to it. First, she holds that the persons who make the interpretation (e.g. judges) are indeed organs of the State and that their functions and interactions are therefore regulated by laws, the source of which is the State (2006, p. 43, Sawicki, p. 56). Second, and crucially, Stein's strategy is to understand the process of the interpretation of laws as being concluded by a social act. Intellectual acts are performed during the process of interpretation, but the act that fixes the interpretation is not an intellectual act. According to Stein, the interpretative legal process concludes with an enactment, since it says how the law ought to

16 For a good overview of the State's legal tasks and the acts correlated to them, see De Vecchi 2015. 
be understood, and this act, which is social, has the State as its subject. Stein describes the activity of interpretation as follows (2006, p. 43-44, Sawicki, p. 56):

According to its main ingredient, this has to do with purely intellectual acts in which the sense content - according to the enactments - is fulfilled and made explicit. Besides that, admittedly, every such "state authorized" interpretation includes an enactment of the content, [to the effect that] the regulation to be interpreted should be understood in just the way that it does interpret it.

By what kind of act can the State ensure that its interpretation of the law is followed? Stein's answer to this question is that the interpretation can be accompanied by an order, in which the State requires specific persons to adopt such and such a behaviour; here again, a social act is attributed to the State. This order can come with a threat of punishment and coercion (2006, p. 44, Sawicki, p. 56-57). A threat is a social act, and is thus mental, and so its subject can be the State; coercion, by contrast, requires a series of physical acts. However, Stein is able to maintain that acts of coercion are nonetheless under the control of the State while avoiding attributing to the State any bodily action. Her claim seems to be this: the physical acts required by coercion, though not acts of the State, remain under its control because they are done in conformity with laws, or more importantly, they are based on specific orders given by organs of the State to civil servants and other auxiliary persons. Thus, although the acts in question are performed by civil servants and other auxiliary persons, they are performed in accordance with laws and orders promulgated by the State. The relation of representation does not hold for the bodily actions themselves, but does hold for the enactment of laws and the orders, which thus have the State as their subject. For Stein, the "activity of ordering” (Befehlstätigkeit) is crucial in the life of the State: thanks to this activity, acts attributed to other persons remain under State's control. In this case too, the "reasonings" (Überlegungen) and "wishes" (Wünsche) underlying the order do not belong to the State, but the order itself has the State as its subject (2006, p. 45-46, Sawicki, p. 59; for a criticism of Stein's account of order, see Schuhmann 2004, p. 180). In short, all acts that are required for the pronouncement of laws are social - mainly enactments and orders.

As regards the executive function of the State, Stein follows a similar strategy. The application of laws requires the existence of an administration, which itself depends on organizational laws made by the State. Threat and coercion are also required in that context: even in extrajudicial contexts, the State gives orders to individual persons and forces these persons to execute the orders (2006, p. 45 and 47, Sawicki, p. 59 and 61). Here too, physical acts come into play, but they remain under the State's control by being conformed to specific enactments and orders given by the State; the State becomes the subject of the enactments and the orders via the relation of representation that holds between it and its organs. 
Finally, as regards the entrepreneur function, it seems that some of the acts that it requires are social, but are distinct from enactments. For example, the State's commercial transactions are based on contracts, which are made in the name of the State itself by its representatives (for contracts as social acts, see Reinach 1913a, p. 171 n. 1). Indeed, many activities linked to the entrepreneurship of the State are done through contracts; for example, when building schools, the State hires architects, builders, plumbers, etc., and buys desks, chairs, etc. Other acts that are required by the State's entrepreneurial activity are all under its control via orders: the State has a large number of persons "at its disposal" (zur Verfügung) and it assigns them specific roles for the execution of this or that act (2006, p. 45-46, Sawicki, p. 59). ${ }^{17}$ Here again, the contracts and the orders are attributed to the State via a relation of representation that it enters with its organs.

\section{Evaluation}

I will now critically assess Stein's attribution of acts to the State. I will first discuss the problems that arise from her account of representation. This relation might seem inadequate for explaining the genesis of the State; moreover, instead of holding between pre-existing relata, it rather seems to produce one of them. I will then broaden the discussion and point out that Stein's view is underdetermined with respect to the ontological status of the State itself. However, while defending her eidetic account of the State, I will also argue that her fine-grained distinctions about the acts that can be attributed to the State remain valuable nevertheless.

A first criticism that one might make of Stein's account of representation concerns the difficulties in explaining the genesis of the State via this relation. In order to be able to establish laws, the State must assign the right to do this to itself. This is an enactment, but the State does not exist before this first enactment (2006, p. 34 and 48, Sawicki, p. 40 and 62):

The first law that must be made and recognized so that further laws can attain validity is the right to make law. [...] State and right come to life together.

Now, like every enactment, this social act must be ascribed to the State via an agent, who has a proxy to do so; but how can the agent have this proxy if the State does not exist before the agent fulfils his obligation as a representative? Representation requires a sort of "meta-social act" between two pre-existing subjects, by which one

17 The importance of acts of ordering is mentioned by Stein in her discussion of the State's entrepreneurial function, but I think that it applies to the judicative and executive functions as well. 
subject gives to the other the right to act in his or her name. ${ }^{18}$ In other words, there is a specific problem of circularity here: the State is presupposed as the entity which designates as a proxy the person meant to perform the acts which are foundational for the State. This echoes contemporary discussions on the circularity of the foundation of collective persons. For example, a circularity objection is used against Gilbert's theory of the "plural subject" (2006). Gilbert holds that individuals build a plural subject by jointly committing themselves to something; however, critics then wonder whether "the formation of a joint commitment [does] not already presuppose the sort of joint action by plural subject it is meant to bring about" (see Schweikard and Schmid 2013). The idea is that the building of a collective person is already a collective action, and thus presupposes the kind of entity it is meant to found. The problem identified in Stein is an interesting variant of the circularity issue. It shows that the circularity problem in social ontology also applies to cases in which social entities are supposed to be self-founding, for it seems that even before they have been founded they must command individual persons to found them.

However, there seems to be a way out for Stein. According to Mulligan, to avoid circularity here, one can use a distinction found in Stein between States constituted "due to spontaneous, non-intended behaviour" and "jurally constituted States": a State of the first sort does not require an enactment for its foundation, but it is nonetheless a State and not a social structure of some other kind, because it is sovereign. This State designates an organ as a proxy to found a jurally constituted State. In other words, States of the first sort emerge spontaneously, and not via any kind of self-foundation; this allows them to found a State of the second kind (on all this, see Mulligan 2015, p. 34-35, as well as Stein 2006, p. 81 and 84, Sawicki, p. 107-108 and 111).

However, the relation of representation is problematic not only with respect to the foundation of the State, but for every attribution of an act. Stein usually speaks as if the State, through the relation of representation, were delegating power to its organs. However, she also adds on one occasion that this is just a "metaphor" (Bild), since the State does not exist "before" its organs, but "reveals itself" only through them (2006, p. 38, Sawicki, p. 49). But then, in what sense are the organs still representing another subject? In order for representation to occur, there must be two persons: a representative person and a represented person. Here there is only one person, the representative, which apparently "invents" a represented subject to which it attributes certain acts; that is, one relatum of the relation produces the other relatum thanks to the relation in question. It seems then that the organs that establish the laws are the only subjects of the actions of enactment. In other words, the core of the State, the legislative subject, is nothing

18 On these “meta-social acts”, or “proxy acts”, see Reinach 1913a, p. 227-228. I thank an anonymous referee of this journal for this idea. 
other than the individual persons who have the power to legislate, or perhaps the collective person built by their community. This holds, mutatis mutandis, for the interpretative, executive, and entrepreneurial functions of the State, and it casts doubt on the very existence of the State as an entity in its own right.

This problem becomes even more pressing when one inquiries into what exactly the ontological status of the State is according to Stein. Stein treats the State as a "social structure" and considers whether it is a "living together of subjects". However, her account is not entirely clear. When she asks whether the State is a collective person, she seems to answer negatively. Based on the distinction she draws between mass, society, and community, the State most likely qualifies as a community. Yet as indicated above, Stein claims that, although the State necessarily has an underlying community, the State itself is not this community (2006, p. 38, Sawicki, p. 48). The State is not equated with the community which is subjected to it, nor can it be identified with a collective person ruling this underlying community: a State does not require a plurality of persons to be in charge of legal decisions, since monarchies are also States, according to Stein. But then what is the State, and in what sense is it a "social structure"? As defended by Loidolt (2010, p. 115-116), the State seems to have its "proper form of existence". It is a legal subject, that is, it is the bearer of the social acts required by its sovereignty, which is explained in terms of legal prerogatives: the State is responsible for establishing laws, which is done via enactments, and for other sorts of acts that are required for the interpretation and application of laws. What Stein seems to hold is that the State is a proper subject of acts, and even though it is not itself a collective person, it has such a collective person within its sphere of power. But if that is the case, the State is not a social structure in the sense of a "living together of subjects" (Zusammenleben von Subjekten) (2006, p. 5, Sawicki, p. 2), but rather in the sense of something which requires an underlying "living together". However, the exact nature of this entity remains undetermined. Such underdetermination might reinforce the intuition that the positing of a social entity like the State is a pernicious ontological temptation.

So what might be Stein's reason for positing an entity like the State? Her motivation is not clear. She sometimes seems to suggest that it would make no sense to attribute the acts of the State to the persons playing the role of organs, but without giving further reasons why (2006, p. 38, Sawicki, p. 48):

The State can execute acts only in that persons who "stand in for" the State execute them for it. Yet such acts have a sense only as acts of the State and not as acts of persons or of bodies that are not characterized as "organs of the State."

This claim is problematic. As seen above, the core of the State, the legislative subject, might be understood as being nothing more than the individual persons 
who have the power to legislate, or perhaps the collective person that they build as a community. Thus, one might take it to be a "mere façon de parler" to say that they are acting for some third entity. Stein herself holds that, in a State, one part of the people "(or in the extreme case, all of them) govern the others in the name of the whole structure” (2006, p. 75, Sawicki, p. 99, slightly modified). It seems to follow that the persons who are governing are doing so in their own name. Even in Stein's own framework, the volitional position-takings which are at the basis of the social acts of enactments and orders of the State are not attributed to the State. Thus, even Stein agrees that the law and its execution reflect the will of those who have the power to produce and apply it. Why not then agree that the persons who are ruling do so in their own name?

One way to solve the problem might be dismiss too narrow a view about ontological entities. One might think that ultimately the State is produced simply by the various ascriptions of acts made by the organs and by the submission to it by its members. In such a deflationary reading, the State would be nothing more than the entity in the name of which the organs act and the entity to which the members of the underlying community give their placet. It would thus depend for its existence on a complex network of acknowledgements from the side of both the organs and the members. It would not so much be an entity that would, so to speak, "autonomously" emerge over and above the individual or collective persons playing the role of the organs as well as the members of the State, but rather would be some sort of intentional object produced collectively by all these persons. ${ }^{19}$ Although it is not clear from the textual evidence that Stein would subscribe to this reading, it is interesting inasmuch as it leads to a much less mysterious description of the nature of the State. ${ }^{20}$

Notwithstanding the underdetermination of Stein's description of the nature of the State, her theory of the acts attributed to the State remains valuable. Beyond Stein's own motivation for accepting an entity such as the State, there are independent arguments developed in contemporary literature for positing social entities. ${ }^{21}$ I will not evaluate these arguments here, but I would like to emphasize that once social entities are accepted, a further question remains to be answered, namely: What kinds of act can we attribute to them? The interesting point is that Stein identifies specific criteria for acts to be attributed to

19 For a detailed presentation of the structure of communal experiences in Stein, see Caminada 2015.

20 I thank an anonymous referee of this journal for the reading.

21 For defences of the existence of collective persons, see Gilbert 2006, who accepts "plural subjects", or Pettit 2014, who speaks of "group agents"; for more on this, see Schweikard and Schmid 2013. 
the State, which relate to its essential properties: given that it is essential to the State to be sovereign, and that sovereignty is understood in terms of being the source of its law, then there are certain acts the State must do in order to be such a source of law, namely, producing laws. Moreover, in order for the production of law to be achieved, certain further acts are required, namely, those linked to the pronouncement and execution of laws. The State must also take on these acts. Stein adds that the State has still another task, that of acting as an "entrepreneur". When Stein lists the things that the State does as an entrepreneur, she mentions together both activities performed by minimalist liberal States, and those performed by welfare States. It is not clear whether she maintains that the State's role as an entrepreneur (or at least part of that role) is an essential feature of this social structure. It is likely, however, that the activities proper to the welfare State, although warranting some positive relation between the State and the citizens, are not essential attributes of the State, as shown by the existence of liberal States.

A general objection that could be made here against Stein is to the very idea of an eidetic theory of the State. What allows Stein to hold that there are essential features of the State? A counterargument to her eidetic view could run as follows: among the things that we accept as "States", some do not have sovereignty as one of their features, e.g. the State of New York, which is submitted to the sovereignty of the USA. Stein seems to anticipate the objection by holding that such a claim does not allow one to draw any conclusion about the essence of the State, but has only to do with our linguistic practices. As she argues, we use the word "State" for two different kinds of thing: first, for any more or less closed community that regulates the life of its members, but which may have lost the mastery of some of its "functions" to a State in the second sense; and, second, for sovereign social structures (2006, p. 16 n. 39, Sawicki, p. 15 n. 35). Her idea seems to be that the equivocity of the word "State" is not as such an argument against an eidetic account, since she is interested in what "State" in the second sense refers to. The claim amounts to saying that there are some social structures which have the specific feature of being "sovereign", which in turn implies a series of other features (producing laws, etc.), and that this kind of entity deserve a detailed analysis both of its nature and of its differences from other social structures. Note that this would be compatible with a more modest claim about essentialism: Stein's analysis of the State would still hold if one were to say that the sovereignty of the State is explainable not by ideal Platonic essences, but rather by the fact that we sometimes use the word "State" to refer only to sovereign social structures. In that case, essentialism about the State would mean simply that there is a given set of items which have the feature of sovereignty and that we pick them out in a distinctive manner with one meaning 
of the word "State”. Stein's inquiries would then still be relevant for the understanding of these sovereign social structures. ${ }^{22}$

One could further object that there is perhaps an essence of the State, but that Stein's own account is flawed, since she makes some erroneous claims about the sovereignty of the State. Indeed, Stein holds that one could imagine a State not only elsewhere than on Earth, but also without any territory. Could not one say that the very notion of sovereignty contradicts this last claim, in the sense that laws hold only on the specific territory in which they are in force ${ }^{23}$ To this objection, one might answer that it is not clear why merely mental beings such as angels could not be thought of as being organized in the form of a sovereign social structure: they could decide democratically about their chains of thoughts, or they could live in a monarchy in which an angel-King or -Queen would impose the rules to which they must submit their mental life; they could have some specific tasks - to begin with, that of transmitting messages (as the Greek world

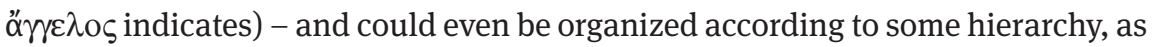
is indeed often the case in angelology (see Reiterer et al. 2007). Moreover, there could exist some coercive ways to ensure that the rules to which they are submitted are respected; for example, an all-mighty spiritual being might be able to produce unpleasant feelings in the mind of the angels who do not follow the laws of the State. This would be an odd State, to be sure, but a State nonetheless.

Once it is accepted that Stein's eidetic theory of the State is plausible, and that sovereignty is an essential feature of the State, her reasons for the ascription of acts to the State become clear: the State must be capable of acting if it is to fulfil its legal prerogatives. Now, an interesting aspect of her position is that, among mental acts, she identifies with great precision those acts which are required by these legal prerogatives: enactments and other social acts like orders or contracts are to be ascribed to the State, but the underlying cognitive and volitional acts on which social acts are based are not acts of the State, nor are reasonings and feelings, nor the bodily activities and actions that are concomitant with the social acts in question. So, for example, in the conclusion of a contract by the State, the thoughts or the feelings had by the civil servant during negotiations or the movement of her hand signing the document are not acts of the State. Although no bodily action is attributed to the State, Stein has a way to keep coercion under its control: policemen, for example, act (or should act) in conformity with laws or according to orders, which are both social acts; similarly, the bodily actions required by the entrepreneurial task of the State remain under its control via laws, orders, and contracts, which are all social acts.

22 I thank one of this journal's anonymous referees for suggesting this idea.

23 I thank an anonymous referee of this journal for the objection. 
Another objection that one might raise is directly related to Stein's account of mental acts. As noted above, social acts are spontaneous intentional mental acts. Now, one might think that it is essential to all mental acts, including all intentional mental acts, to come with something like a subjective character, that is, some sort of "phenomenal consciousness" (on these questions, see, among others, Kriegel 2013). It has even been recently claimed by Overgaard and Salice (Forthcoming) that such an argument might lead one to reject a variant of the "Group Mind Hypothesis". On this hypothesis, collectives have beliefs of their own, over and above those of the individuals which constitute them, although they do not have collective "phenomenal consciousness". Overgaard and Salice object that beliefs necessarily come with consciousness, including phenomenal consciousness; thus, denying that collectives have phenomenal consciousness makes it impossible to ascribe beliefs to them. But does the State as such have phenomenal consciousness? If not, would not that render Stein's idea of acts genuinely performed by States implausible? Contrary to what one might think, however, in answering this objection there is no need to enter into the question whether the State is the bearer of phenomenal consciousness. Indeed, it is proper to the relation of representation in general that the person represented, despite becoming the subject of the social act thanks to the relation in question, has no consciousness of this act. Consider a standard case of representation: when someone makes a contract in the name of someone else, this other person (usually) has no consciousness of the social act of making the contract, despite becoming the subject of this act. Likewise, the State's being possibly deprived of phenomenal consciousness is not as such a counterargument to Stein's claim that it becomes the subject of social acts thanks to representation. On the contrary - and this is an additional interesting point in her theory - her "representationalist" account of the ascription of acts to the State is independent of whether social structures have phenomenal consciousness. Thus, the argument against the Group Mind Hypothesis cannot be transposed to the attribution of social acts to the State, since those acts do not require a subject to be conscious of them in order for them to be ascribed to it via a relation of representation. ${ }^{24}$

One question that remains to be asked is whether all the acts done by the State are social. Stein's answer is no: she holds that some acts of the State are not “addressed to anyone”, and gives States' "resolutions" (Beschluss) as examples.

24 Stein discusses similar issues at length, and does attribute experiences to collectives ("supraindividual experiences”), while denying that a collective is itself conscious of these experiences; consciousness is reserved to the individual members that ground the collective (for more on this, see 2010, p. 112-162, esp. §1). This would again be rejected by Overgaard and Salice (Forthcoming), at least with regard to beliefs. A detailed defence of Stein's thesis that collectives can have experiences without consciousness, and a comparison with Overgaard and Salice (Forthcoming), would be interesting, but is beyond the scope of this paper. 
Unfortunately, Stein does not explain further what she means by "resolution", nor does she provide specific examples. Is she referring to those acts in which an institution says how people should behave, but which are non-binding? Does she mean that a resolution is a declaration of intent, and that it is thus not a social act, but a mere linguistic exteriorization of an internal state? Stein's view on these issues is not clear. She adds that even in cases where the acts of the State are not addressed to anyone, they always have "indirect or direct social consequences” (2006, p. 50, Sawicki, p. 65). This formulation is mysterious; perhaps it means that acts of the State, when they do not produce rights and obligations, at least mention the rights and obligations that the State would like people to be the subject of. Or perhaps it means more broadly that any kind of action that results from acts of the State, for example the building of a bridge, has social consequences in the sense that it affects the life of the community underlying the State. The possibility that some acts of the State are not social acts introduces a further difficulty: acts can be ascribed to the State by means of the relation of representation, and it is likely that this relation holds only for the ascription of social acts, since it is presented as a "modification" of such acts (see Reinach 1913a, p. 165 and 223). But then, if Stein agrees that acts other than social ones can be ascribed to the State, by what means is this possible? The choice would be either to find another relation which would perform this function, or to accept that representation applies not just to social acts, but to other acts as well. None of these hypotheses is developed by Stein.

Independently of this final complication, Stein has an original and elegant theory of the ascription of acts to the State, one which restricts this ascription according to the status of the State as essentially a legal entity, and which is based on a fine-grained eidetic-phenomenological analysis of mental acts.

\section{Conclusion}

For Stein, the acts attributed to the State are above all those required by the production, interpretation, and application of law, or what she calls the "administration of law" (Rechtspflege). The two most important kinds of act are enactments (i.e. the establishing of laws), and orders, which allow not only for the law's application, but also for other kinds of State's activities, including those linked with its "entrepreneurial" function. These acts are social and they are performed by the organs of the State and in its name. Only persons can perform such acts, and the State is not a person; however, it becomes the subject of those acts thanks to the relation of representation. The underlying cognitions and volitions on which social acts are based are not to be attributed to the State, nor are any reasonings, feelings, or concomitant bodily activities and actions. Thus, in an interesting 
combination of essential inquiry about the State and fine-grained eidetic-phenomenological distinctions among mental acts, Stein arrives at a complex picture of why and how some acts belong to the State. One might object that there is an underdetermination in her texts with respect to the ontological status of the State, and that this, together with the difficulties inherent in her account of representation, casts doubt on the existence of such an entity; however, if one accepts that there are social subjects and that the State is one of them, Stein's fine-grained analysis of the acts that can be attributed to the State shows itself to be of great value. ${ }^{25}$

\section{Bibliography}

Calcagno, Antonio (2014): Lived Experience from the Inside Out: Social and Political Philosophy in Edith Stein. Pittsburgh: Duquesne University Press.

Caminada, Emanuele (2015): “Edith Stein's Account of Communal Mind and Its Limits: A Phenomenological Reading”. In: Szanto, Thomas/Moran, Dermot (Eds.): Empathy and Collective Intentionality: The Social Philosophy of Edith Stein. Human Studies 38. No. 4, p. 549-566.

De Vecchi, Francesca (2015): “Edith Stein's Social Ontology of the State, the Law and Social Acts: An Eidetic Approach”. In: Studia Phaenomenologica 15, p. 303-330.

De Vecchi, Francesca (2017): "Eidetics of Law-Making Acts: Parts, Wholes and Degrees of Existence”. In: Phenomenology and Mind 13, p. 86-95.

Gilbert, Margaret (2006): A Theory of Political Obligation. Oxford: Oxford University Press.

Gombócz, Wolfgang L. and Alessandro Salice (2006): “Edith Steins soziale Ontologie auf Grund ihrer Staatsschrift”. In: Aufgang. Jahrbuch für Denken, Dichten, Musik 3, p. 436-456.

Green, Mitchell (2014): “Speech Acts”. In: Edward N. Zalta (Ed.): Stanford Encyclopedia of Philosophy. Stanford. plato.stanford.edu/entries/speech-acts.

Hildebrand, Dietrich von (1916): “Die Idee der sittlichen Handlung”. In: Jahrbuch für Philosophie und phänomenologische Forschung 3, p. 126-252.

Husserl, Edmund (1975 and 1984): Logische Untersuchungen. In: Husserliana, vol. XVIII and XIX/1-2. Panzer, Ursula (Ed.). The Hague: Martinus Nijhoff.

Kriegel, Uriah (2013): Phenomenal Intentionality. Oxford: Oxford University Press.

Loidolt, Sophie (2010): Einführung in die Rechtsphänomenologie: Eine historisch-systematische Darstellung. Tübingen: Mohr Siebeck.

Loidolt, Sophie (2015): "Legal Reality and its A Priori Foundations - A Question of Acting or Interpreting? Felix Kaufmann, Fritz Schreier and Their Critique of Adolf Reinach”. In: Alessandro Salice and Hans Bernhard Schmid (Eds.): The Phenomenological Approach to Social Reality. Cham: Springer, p. 47-73.

Magrì, Elisa and Dermot Moran (Eds.) (2017): Empathy, Sociality, and Personhood: Essays on Edith Stein's Phenomenological Investigations. Cham: Springer.

25 A first draft of this paper was presented at the conference "Phenomenology of Action and Volition" in Prague in 2018. I am grateful to the participants for their helpful remarks, especially Guillaume Fréchette, Jo-Jo Koo, Kevin Mulligan, and Alessandro Salice. I also thank three referees of this journal for their valuable comments on previous drafts. 
Mulligan, Kevin (1987): "Promisings and Other Social Acts: Their Constituents and Structure". In: Kevin Mulligan (Ed.): Speech Act and Sachverhalt: Reinach and the Foundations of Realist Phenomenology. Dordrecht: Martinus Nijhoff, p. 29-90.

Mulligan, Kevin (2015): "Persons and Acts - Collective and Social: From Ontology to Politics". In: Alessandro Salice and Hans Bernhard Schmid (Eds.): The Phenomenological Approach to Social Reality. Cham: Springer, p. 17-45.

Overgaard, Søren and Alessandro Salice (Forthcoming): “Consciousness, Belief, and the Group Mind Hypothesis", Synthese.

Pettit, Philip (2014): “Three Issues in Social Ontology”. In: Julie Zahle and Finn Collin (Eds.): Rethinking the Individualism-Holism Debate. Cham: Springer, p. 77-96.

Reinach, Adolf (1989 [1911]): “Zur Theorie des negativen Urteils”. In: Adolf Reinach, Sämtliche Werke, vol. 1. Karl Schuhmann and Barry Smith (Eds.). Munich: Philosophia, p. 95-140.

Reinach, Adolf (1989 [1913a]): Die apriorischen Grundlagen des bürgerlichen Rechtes. In: Adolf Reinach, Sämtliche Werke, vol. 1. Karl Schuhmann and Barry Smith (Eds.). Munich: Philosophia, p. 141-278; transl. Crosby, John F. (1983). In: Aletheia 3, p. 1-142.

Reinach, Adolf (1989 [1913b]): “Einleitung in die Philosophie”. In: Adolf Reinach, Sämtliche Werke, vol. 1. Karl Schuhmann and Barry Smith (Eds.). Munich: Philosophia, p. 369-513.

Reinach, Adolf (1989 [1914]): “Über Phänomenologie”. In: Adolf Reinach, Sämtliche Werke, vol. 1. Karl Schuhmann and Barry Smith (Eds.). Munich: Philosophia, p. 531-550.

Reiterer, Friedrich V., Tobias Niklas and Karin Schöpflin (Eds.) (2007): Angels: The Concept of Celestial Beings - Origins, Development and Reception. Berlin: De Gruyter.

Salice, Alessandro (2015): “The Phenomenology of the Munich and Göttingen Circles”. In: Edward N. Zalta (Ed.): Stanford Encyclopedia of Philosophy. Stanford. plato.stanford.edu/ entries/phenomenology-mg.

Salice, Alessandro (2016): "Collective Intentionality and the Collective Person in Max Scheler". In: Sonja Rinofner-Kreidl and Harald A. Wiltsche (Eds.): Analytical and Continental Philosophy: Methods and Perspectives. Berlin: De Gruyter, p. 277-288.

Scheler, Max (1980): Der Formalismus in der Ethik und die matierale Wertethik. 6th ed. Manfred S. Frings and Maria Scheler (Eds.). Bern: Francke.

Schuhmann, Karl (2004): “Edith Stein und Adolf Reinach”. In: Cees Leijenhorst and Piet Steenbakkers (Eds.): Karl Schuhmann. Selected Papers on Phenomenology. Dordrecht: Kluwer, p. 163-184.

Schweikard, David P. and Hans Bernhard Schmid (2013): “Collective Intentionality”. In: Edward N. Zalta (Ed.): Stanford Encyclopedia of Philosophy. Stanford. plato.stanford.edu/entries/ collective-intentionality.

Stein, Edith (2004): Einführung in die Philosophie. In: Edith Stein Gesamtausgabe, vol. VIII. Claudia M. Wulf (Ed.). Freiburg: Herder.

Stein, Edith (2006): Eine Untersuchung über den Staat. In: Edith Stein Gesamtausgabe, vol. VII. Ilona Riedel-Spangenberger (Ed.). Freiburg: Herder.

Stein, Edith (2008): Zum Problem der Einfühlung. In: Edith Stein Gesamtausgabe, vol. V. Maria A. Sondermann (Ed.). Freiburg: Herder.

Stein, Edith (2010): Beiträge zur philosophischen Begründung der Psychologie und der Geisteswissenschaften. In: Edith Stein Gesamtausgabe, vol. VI. Beate Beckmann-Zöller (Ed.). Freiburg: Herder.

Szanto, Thomas and Dermot Moran (eds.) (2015): Empathy and Collective Intentionality: The Social Philosophy of Edith Stein. Human Studies 38. No. 4.

Tönnies, Ferdinand (2016): Gemeinschaft und Gesellschaft: Grundbegriffe der reinen Soziologie. Arno Bammé (Ed.). Munich: Profil-Verlag. 